\title{
MECHANISM OF RESISTANCE TO AMINOGLYCOSIDE ANTIBIOTICS IN NEBRAMYCIN-PRODUCING STREPTOMYCES TENEBRARIUS
}

\author{
Hirokazu Yamamoto*, Kunimoto Hotta, Yoshiro Okami \\ and Hamao UmezaWA \\ Institute of Microbial Chemistry \\ 3-14-23 Kamiosaki, Shinagawa-ku, Tokyo 141, Japan
}

(Received for publication February 24, 1982)

\begin{abstract}
Streptomyces tenebrarius ISP 5477, which produces nebramycins, was highly resistant to the following aminoglycoside antibiotics: neamine, ribostamycin, butirosin $\mathrm{A}$, neomycin $\mathrm{B}$, paromomycin, kanamycin $\mathrm{A}$, dibekacin, gentamicin $\mathrm{C}$ complex, lividomycin $\mathrm{A}$, istamycin $\mathrm{B}$ and streptomycin. Polyphenylalanine synthesis on the ribosomes of this strain was highly resistant to neamine, ribostamycin, butirosin $\mathrm{A}$, kanamycins $\mathrm{A}, \mathrm{B}$ and $\mathrm{C}$, dibekacin, gentamicin $\mathrm{C}$ complex and istamycin $\mathrm{B}$, moderately resistant to lividomycin $\mathrm{A}$ and streptomycin, but sensitive to neomycin B and paromomycin. Moreover, cell free extract of the strain contained phosphotransferase and $\mathrm{N}$-acetyltransferase. The former enzyme was confirmed to be an aminoglycoside 6-phosphotransferase which inactivated streptomycin; the latter inactivated kanamycins B and C, dibekacin, neamine, neomycin B, paromomycin, lividomycin A, butirosin $\mathrm{A}$ and ribostamycin, but did not inactivate kanamycin $\mathrm{A}$, gentamicin $\mathrm{C}$ complex and sagamicin, suggesting an aminoglycoside 2 '-acetyltransferase.

These results indicated that the high resistance of S. tenebrarius ISP 5477 to a wide range of aminoglycoside antibiotics is due to ribosomal resistance and to the inactivating enzymes, aminoglycoside $\mathrm{N}$-acetyltransferase(s) and aminoglycoside 6-phosphotransferase.
\end{abstract}

Aminoglycoside antibiotic-producing streptomycetes are resistant to their own antibiotics ${ }^{1)}$, and each producer shows a characteristic resistance pattern against other aminoglycoside antibiotics ${ }^{2,3)}$. The resistance of some strains has been confirmed to be due to their aminoglycoside-inactivating enzymes. For example, the resistance pattern of neomycin-producing $S$. fradiae ISP 5063 is consistent with the substrate specificity of an aminoglycoside 3-phosphotransferase ${ }^{3)}$ produced by this strain. A similar enzymatic mechanism was confirmed for the resistance of kanamycin-producing S. kanamyceticus ISP 55003) to various aminoglycoside antibiotics. On the other hand, S. tenjimariensis SS-939, which produces istamycins, has no inactivating enzymes, but possesses resistant ribosomes to istamycins ${ }^{4)}$, and the characteristic resistance pattern of strain SS-939 to various aminoglycoside antibiotics was confirmed to be dependent on its ribosomal resistance ${ }^{2)}$.

Among the aminoglycoside antibiotic-producing streptomycetes tested, nebramycin-producing $S$. tenebrarius ISP 5477 showed the widest range of resistance: it was highly resistant to all aminoglycoside antibiotics tested. Therefore, we were interested in the resistance mechanisms of this strain. As reported in this paper, both ribosomal and enzymatic resistance mechanisms were found to operate in this strain.

\section{Materials and Methods}

Organisms

Streptomyces tenebrarius ISP 5477, derived from ATCC 17920,6), and Streptomyces griseus ISP

* Present address: Central Research Laboratories, Yamanouchi Pharmaceutical Co. Ltd., 1-1-8, Azusawa, Itabashi-ku, Tokyo, Japan. 
5236 were used. Streptomyces sp. SS-1227 was isolated from soil in our laboratory.

Antibiotics

Istamycin B, kanamycins $\mathrm{A}, \mathrm{B}$ and $\mathrm{C}$, dibekacin, gentamicin $\mathrm{C}$ complex, neamine, neomycin $\mathrm{B}$, ribostamycin, paromomycin, lividomycin $\mathrm{A}$, butirosin $\mathrm{A}$ and streptomycin were obtained from the collection of antibiotics of the Institute of Microbial Chemistry. Sagamicin was supplied by Kyowa Hakko Kogyo Co. Ltd.

Determination of Antibiotic Resistance

Cultures of S. tenebrarius ISP 5477 in logarithmic growth phase in Tryptic Soy Broth (TSB; Difco) at $27^{\circ} \mathrm{C}$ on a rotary shaker were transferred after a dilution of $1: 100$ into $2 \mathrm{ml}$ of fresh medium containing the above antibiotics at various concentrations. Growth was measured after incubating at $27^{\circ} \mathrm{C}$ for 3 days on a reciprocal shaker.

\section{In Vitro Polyphenylalanine Synthesis}

Poly-U-directed polyphenylalanine synthesis was carried out according to the method previously described $^{4)}$, except that reaction mixture was $100 \mu \mathrm{l}$ in total volume and ribosomes were added at a final concentration of $17 \mathrm{~A}_{280}$ units/ml.

\section{Preparation of Crude Enzyme Solution (S150)}

Mycelia of S. tenebrarius ISP 5477 grown in TSB medium were collected at the mid-logarithmic growth phase and washed with buffer $\mathrm{A}\left(10 \mathrm{ml}\right.$ tris- $\mathrm{HCl}, \mathrm{pH} 7.8,60 \mathrm{~mm} \mathrm{NH}_{4} \mathrm{Cl}, 10 \mathrm{~mm}$ magnesium acetate and $1 \mathrm{~mm}$ dithiothreitol). Packed mycelia were then disrupted by grinding with alumina and extracted with buffer A. After removal of alumina and cell debris by centrifugation, the supernatant was centrifuged at $150,000 \times g$ for 2 hours and the supernatant (designated as S150) was stored at $-80^{\circ} \mathrm{C}$.

\section{Enzyme Assay}

Phosphorylation of antibiotics by $\mathrm{S} 150$ was carried out in a reaction mixture $(100 \mu \mathrm{l})$ containing 80 $\mathrm{mm}$ tris- $\mathrm{HCl}$ ( $\mathrm{pH} 7.8), 2 \mathrm{~mm}$ magnesium acetate, $2 \mathrm{~mm}$ dithiothreitol, $4 \mathrm{~mm} \gamma^{-32} \mathrm{P}-\mathrm{ATP}(3.36 \mathrm{mCi} / \mathrm{mmole}$, $\mathrm{NEN}$ ), $20 \mu \mathrm{l} \mathrm{S} 150$ and $100 \mu \mathrm{g} / \mathrm{ml}$ antibiotic. After incubation at $30^{\circ} \mathrm{C}$ for 60 minutes, $20 \mu \mathrm{l}$ of the reaction mixture was dropped onto a piece of phosphocellulose paper (Whatman P81, $1.5 \times 1.5 \mathrm{~cm})^{7}$. It was then immersed into water at $85^{\circ} \mathrm{C}$ for 2 minutes and washed three times with large volume of deionized water. Radioactivity retained on the papers was counted in a liquid scintillation counter. Background values of the control reaction mixture without any antibiotic were subtracted from the total counts.

Acetylation or adenylylation of antibiotics was examined under the same conditions as described for phosphorylation except that $0.2 \mathrm{~mm}\left[1-{ }^{14} \mathrm{C}\right]$ acetylCoA $(5 \mathrm{mCi} / \mathrm{mmole})$ or $2 \mathrm{~mm}{ }^{14} \mathrm{C}-\mathrm{ATP}(100 \mu \mathrm{Ci} /$ mM) was used instead of $\gamma^{32}$ P-ATP.

Preparation, Isolation and Characterization of Phosphorylated Dihydrostreptomycin

Dihydrostreptomycin sulfate was subjected to the phosphotransferase in $\mathrm{S} 150$ in a reaction mixture $(360 \mathrm{ml})$ containing $80 \mathrm{~mm}$ tris- $\mathrm{HCl}(\mathrm{pH} 7.8), 1 \mathrm{~mm}$ magnesium acetate, $1 \mathrm{~mm}$ dithiothreitol, $4 \mathrm{~mm}$ ATP, $\mathrm{S} 150(40 \mathrm{ml})$ and dihydrostreptomycin $(180 \mathrm{mg})$. The reaction mixture was incubated at $30^{\circ} \mathrm{C}$ for 16 hours and the phosphorylated product was adsorbed on a column of Bio-Rex 70 resin $\left(\mathrm{NH}_{4}{ }^{+}: \mathrm{H}^{+}=\right.$ 7: 3), eluted with $0.4 \mathrm{~N} \mathrm{NH}_{4} \mathrm{OH}$ and freeze-dried. Approximately $120 \mathrm{mg}$ of the reaction product was obtained by column chromatography with Sephadex G-15 (eluted with $20 \mathrm{~mm} \mathrm{NaHCO}_{3}$ ). The position of phosphorylation was determined from the ${ }^{13} \mathrm{C}$ NMR spectrum of the phosphorylated dihydrostreptomycin in comparison with that of dihydrostreptomycin. All 21 carbon atoms of both compounds were identified and the C- 6 peak shift to the lower field of the phosphorylated product was assigned according to the report of BocK et al. . $^{8}$

\section{Results}

Antibiotic Resistance of S. tenebrarius ISP 5477 In Vivo and In Vitro

S. tenebrarius ISP 5477 grew well in TSB in the presence of $1,000 \mu \mathrm{g} / \mathrm{ml}$ of all the following anti- 
biotics: neamine, ribostamycin, butirosin $\mathrm{A}$, neomycin $\mathrm{B}$, paromomycin, lividomycin $\mathrm{A}$, kanamycin $\mathrm{A}$, dibekacin, gentamicin $\mathrm{C}$, istamycin $\mathrm{B}$, and streptomycin. Among the aminoglycoside antibiotic-producing actinomycetes tested, S. tenebrarius ISP 5477 showed the highest resistance to the widest range of aminoglycoside antibiotics. As shown in the left column of Table 1, polyphenylalanine synthesis in the cell free extract containing ribosomes and S150 fraction was also highly resistant to all antibiotics tested.

\section{Ribosomal Resistance to Aminoglycoside Antibiotics}

The ribosomes of strain ISP 5477 were separated and combined with the S150 fraction prepared from S. griseus ISP 5236 in order to find if the resistance was due to the ribosomes. S. griseus ISP 5236 is sensitive to all aminoglycoside antibiotics except streptomycin and has no inactivating enzyme except streptomycin 6-kinase ${ }^{2,3}$. In order to test the sensitivity of the ribosomes to streptomycin, S150 of a streptomycin-sensitive strain Streptomyces sp. SS-1227 which produced trehalosamine was used.

As shown in Table 1 (right column), the ribosomes were highly resistant to neamine, ribostamycin, butirosin A, kanamycins A, B and C, dibekacin, gentamicin C complex, and istamycin B, and moderately resistant to lividomycin $\mathrm{A}$ and streptomycin, but sensitive to neomycin $\mathrm{B}$ and paromomycin.

Aminoglycoside Inactivating Enzymes

The existence of aminoglycoside inactivating enzyme(s) was suggested from the result that the high resistance of the polyphenylalanine synthesis with cell free extract of strain ISP 5477 to neomycin B,

Table 1. Effect of aminoglycoside antibiotics on in vitro polyphenylalanine synthesis of S. tenebrarius ISP 5477.

\begin{tabular}{|c|c|c|c|c|c|}
\hline \multirow{3}{*}{ Antibiotic $(100 \mathrm{U} / \mathrm{ml})$} & \multirow{2}{*}{\multicolumn{2}{|c|}{ In vivo resistance }} & \multicolumn{3}{|c|}{ In vitro polyphenylalanine synthesis } \\
\hline & & & \multirow{2}{*}{$\begin{array}{l}\text { Ribo- } \\
\text { some } \\
\text { S150 }\end{array}$} & \multicolumn{2}{|c|}{5477} \\
\hline & 5477 & 5236 & & 5477 & 5236 \\
\hline None & - & 一 & & $\begin{array}{c}100.0 \% \\
(19,090 \mathrm{dpm})\end{array}$ & $\begin{array}{c}100.0 \% \\
(20,507 \mathrm{dpm})\end{array}$ \\
\hline Kanamycin A & $\mathrm{R}$ & $\mathrm{S}$ & & 95.8 & 115.0 \\
\hline Kanamycin B & $\mathrm{R}$ & $\mathrm{S}$ & & 80.4 & 83.7 \\
\hline Kanamycin C & $\mathrm{R}$ & $\mathrm{S}$ & & 96.3 & 85.7 \\
\hline Dibekacin & $\mathrm{R}$ & $\mathrm{S}$ & & 79.8 & 68.4 \\
\hline Gentamicin C & $\mathrm{R}$ & $\mathrm{S}$ & & 92.0 & 87.0 \\
\hline Ribostamycin & $\mathrm{R}$ & $\mathrm{S}$ & & 96.8 & 74.8 \\
\hline Butirosin A & $\mathrm{R}$ & $\mathrm{S}$ & & 101.0 & 102.0 \\
\hline Neomycin B & $\mathrm{R}$ & $\mathrm{S}$ & & 80.3 & 33.4 \\
\hline Paromomycin & $\mathrm{R}$ & $\mathrm{S}$ & & 79.4 & 27.9 \\
\hline Lividomycin A & $\mathrm{R}$ & $\mathrm{S}$ & & 99.8 & 50.1 \\
\hline Neamine & $\mathrm{R}$ & $\mathrm{S}$ & & 98.0 & 78.3 \\
\hline \multirow[t]{2}{*}{ Istamycin B } & $\mathrm{R}$ & $\mathrm{S}$ & & 83.7 & 80.2 \\
\hline & 5477 & 1227 & $\mathrm{~S} 150$ & 5477 & 1227 \\
\hline None & - & 一 & & $\begin{array}{c}100.0 \% \\
(16,772 \mathrm{dpm})\end{array}$ & $\begin{array}{c}100.0 \% \\
(11,795 \mathrm{dpm})\end{array}$ \\
\hline Streptomycin & $\mathrm{R}$ & $\mathrm{S}$ & & 75.9 & 45.0 \\
\hline
\end{tabular}

* Incorporation of $\left[{ }^{14} \mathrm{C}\right]$ phenylalanine into TCA insoluble fraction was counted after 45 minutes incubation at $37^{\circ} \mathrm{C}$.

** 5477, 5236 and 1227 refer to S. tenebrarius ISP 5477, S. griseus ISP 5236 and Streptomyces sp. SS-1227, respectively. $\mathrm{R}$ and $\mathrm{S}$ refer to resistant and sensitive, respectively. 
Table 2. Acetylation and phosphorylation of aminoglycoside antibiotics by cell free extract of Streptomyces tenebrarius ISP 5477.

\begin{tabular}{l|ccc}
\hline \multicolumn{1}{c|}{ Antibiotic } & Acetyl* & Phosphoryl* & Adenylyl* \\
\hline Kanamycin A & $395 \mathrm{dpm}$ & $0 \mathrm{dpm}$ & $0 \mathrm{dpm}$ \\
$\mathrm{B}$ & 6065 & $\mathrm{nt}$ & $\mathrm{nt}$ \\
$\mathrm{C}$ & 6565 & $\mathrm{nt}$ & $\mathrm{nt}$ \\
Dibekacin & 5448 & 335 & 0 \\
Gentamicin C & 464 & 0 & 0 \\
$\quad$ complex & & & \\
Sagamicin & 450 & $\mathrm{nt}$ & $\mathrm{nt}$ \\
Neamine & 8732 & 712 & 0 \\
Ribostamycin & 6833 & 0 & 189 \\
Butirosin A & 9232 & 0 & 0 \\
Neomycin B & 6716 & 427 & 31 \\
Paromomycin & 3127 & 36 & 25 \\
Lividomycin & 8867 & 0 & 0 \\
Istamycin & 525 & 0 & 0 \\
Streptomycin & 30 & 9431 & 0 \\
Dihydrostrep- & $\mathrm{nt} * *$ & 9979 & $\mathrm{nt}$ \\
tomycin & & & \\
\hline
\end{tabular}

* Experimental conditions for acetylation, phosphorylation and adenylylation were described in Materials and Methods.

** nt: not tested. paromomycin, lividomycin A and streptomycin was markedly reduced when the S150 of strain ISP 5477 was replaced by that of S. griseus ISP 5236 or Streptomyces sp. SS-1227. In fact, the existence of an aminoglycoside acetyltransferase in S. tenebrarius was reported ${ }^{9}$. Accordingly, the cell free extract was prepared from S. tenebrarius ISP 5477 and incubated with various aminoglycoside antibiotics under the conditions of phosphorylation, acetylation and adenylylation, as described in Materials and Methods (Table 2).

Phosphorylation was observed only with streptomycin and dihydrostreptomycin. To determine the position of phosphorylation, dihydrostreptomycin sulfate was incubated with the cell free extract (S150), and the inactivated product was isolated and purified by ion-exchange column chromatography. The purified product showed a band at $970 \mathrm{~cm}^{-1}$ (phosphoric) in IR spectrum and restored antibiotic activity when treated with alkaline phosphatase. ${ }^{13} \mathrm{C}$ NMR spectrum of the inactivated product in $\mathrm{D}_{2} \mathrm{O}$

showed that the signal assigned to the C-6 of the streptidine moiety of dihydrostreptomycin was shifted by $2.0 \mathrm{ppm}(\delta 75.5 \mathrm{ppm})$ to the lower field. The phosphate on the hydroxyl group of C-6 was also observed by P-C coupling $\left({ }^{2} J \mathrm{c}-\mathrm{p}=6.1 \mathrm{~Hz}\right)$. These results indicate that the inactivated dihydrostreptomycin was dihydrostreptomycin 6-phosphate. Therefore, it was concluded that S. tenebrarius ISP 5477 produced an aminoglycoside 6-phosphotransferase.

In the acetylation experiment, kanamycins $\mathrm{B}$ and $\mathrm{C}$ were efficiently acetylated, but kanamycin $\mathrm{A}$ was not. This indicates that the acetylating enzyme must be an aminoglycoside 2 '-acetyltransferase, because only kanamycin $\mathrm{A}$ out of these three kanamycins lacks the amino group in $2^{\prime}$ position. In addition to kanamycins, the cell free extract acetylated dibekacin, neomycin B, ribostamycin, paromomycin and lividomycin A. However, gentamicin $\mathrm{C}$ complex and sagamicin were not acetylated by the extract, although aminoglycoside $2^{\prime}$-acetyltransferases from Providencia ${ }^{10,11)}$ or S. spectabilis ${ }^{12)}$ were reported to acetylate gentamicins. No adenylylation of all the other antibiotics tested occurred.

\section{Discussion}

Nebramycin-producing $S$. tenebrarius ISP 5477 was found to be highly resistant to all the aminoglycoside antibiotics tested. This wide pattern of resistance is characteristic of this strain, and different from that of other aminoglycoside antibiotic-producing actinomycetes. As summarized in Table 3, ribosomal resistance and enzymatic inactivation were found to be involved in the resistance mechanism to various aminoglycoside antibiotics. The resistance to kanamycins $\mathrm{B}$ (one of the antibiotics produced by strain ISP 5477) and C, dibekacin, neamine, ribostamycin, butirosin A and lividomycin A was found 
Table 3. Resistance mechanism of S. tenebrarius ISP 5477 to aminoglycoside antibiotics.

\begin{tabular}{|c|c|c|c|c|c|}
\hline \multirow{2}{*}{ Antibiotic } & \multicolumn{2}{|c|}{ Resistance* } & \multirow{2}{*}{ Ribosome } & \multirow{2}{*}{$\begin{array}{l}\text { Inactivating } \\
\text { enzyme }\end{array}$} & \multirow{2}{*}{$\begin{array}{l}\text { Resistance } \\
\text { mechanism }\end{array}$} \\
\hline & In vivo & In vitro & & & \\
\hline Kanamycin A & $\mathrm{R}$ & $\mathrm{R}$ & $\mathrm{R}$ & - & Ribosome \\
\hline Gentamicin C & $\mathrm{R}$ & $\mathrm{R}$ & $\mathrm{R}$ & - & Ribosome \\
\hline Istamycin B & $\mathrm{R}$ & $\mathrm{R}$ & $\mathrm{R}$ & - & Ribosome \\
\hline Neamine & $\mathrm{R}$ & $\mathrm{R}$ & $\mathrm{R}$ & $++t$ & Ribosome \& AAC \\
\hline Kanamycins B \& C & $\mathrm{R}$ & $\mathrm{R}$ & $\mathrm{R}$ & +++ & Ribosome \& AAC \\
\hline Dibekacin & $\mathrm{R}$ & $\mathrm{R}$ & $\mathrm{R}$ & +++ & Ribosome \& AAC \\
\hline Ribostamycin & $\mathrm{R}$ & $\mathrm{R}$ & $\mathrm{R}$ & +++ & Ribosome \& AAC \\
\hline Butirosin A & $\mathrm{R}$ & $\mathrm{R}$ & $\mathrm{R}$ & +++ & Ribosome \& AAC \\
\hline Lividomycin A & $\mathrm{R}$ & $\mathrm{R}$ & $\mathrm{pR}$ & +++ & Ribosome \& AAC \\
\hline Neomycin B & $\mathrm{R}$ & $\mathrm{R}$ & (S) & $+t+$ & AAC ( \& ribosome) \\
\hline Paromomycin & $\mathrm{R}$ & $\mathrm{R}$ & (S) & ++ & AAC ( \& ribosome) \\
\hline Streptomycin & $\mathrm{R}$ & $\mathrm{R}$ & $\mathrm{pR}$ & $++t$ & Ribosome \& APH(6) \\
\hline
\end{tabular}

* In vivo : Resistance of $S$. tenebrarius ISP 5477 to the antibiotics in TSB.

In vitro: Resistance of in vitro polyphenylalanine synthesizing system prepared from $S$. tenebrarius ISP 5477. R and $\mathrm{S}$ refer to resistant and sensitive to the antibiotics tested.

to be due to both ribosomes and acetyltransferase, and the resistance to streptomycin was due to both ribosomes and aminoglycoside 6-phosphotransferase. On the other hand, the resistance to istamycin $\mathrm{B}$, kanamycin $\mathrm{A}$ and gentamicin $\mathrm{C}$ complex was conferred by ribosomal resistance. An aminoglycoside acetyltransferase was suggested to play a major role in the resistance to neomycin B and paromomycin. Thus, S. tenebrarius ISP 5477 has a unique mechanism of resistance to a wide range of aminoglycoside antibiotics, a mechanism which is unknown in the other aminoglycoside antibiotic-producing streptomycetes examined so $\mathrm{far}^{2 \sim 4)}$.

The range of resistance of $S$. tenebrarius ISP 5477 ribosome to various aminoglycoside antibiotics was as wide as that of istamycin-producing S. tenjimariensis SS-9392) which is relatively sensitive to neomycin, paromomycin and lividomycin A which consist of more than three sugar moieties. However, ribosomes of $S$. tenebrarius were resistant to gentamicin C complex, but those of $S$. tenjimariensis sensitive. Furthermore, cross resistance between kanamycin and streptomycin was not shown in the ribosomes of S. tenebrarius and S. tenjimariensis. The ribosomal resistance pattern of these two strains suggests that more than one ribosomal protein would be involved in the wide resistance.

$N$-Acetyltransferase of strain ISP 5477 was suggested to be an aminoglycoside 2'-acetyltransferase because of its substrate specificity to kanamycins A, B and C. However, this enzyme did not acetylate gentamicins although aminoglycoside 2 '-acetyltransferases from a clinical isolate of Providencia ${ }^{10,11)}$ and spectinomycin-producing S. spectabilis ${ }^{12}$ are known to acetylate gentamicins. This suggests that the acetyltransferase of S. tenebrarius ISP 5477 is a new type of aminoglycoside $2^{\prime}$-acetyltransferase, or that this strain also produces other acetyltransferases. These two possibilities will be clarified by structure determination of the reaction products of each antibiotic.

An aminoglycoside 6-phosphotransferase, another enzyme found in S. tenebrarius ISP 5477, was suggested to play an important role in the resistance of this strain to streptomycin. The enzyme was also reported to be produced by S. coelicolor ${ }^{12)}$, S. spectabilis ${ }^{12)}$ and $S$. favopersicus ${ }^{13)}$, in which the enzyme might play an important role in the resistance to streptomycin as well.

\section{Acknowledgements}

We are grateful to Dr. Axıo Seino, Kaken Chemical Co., Ltd., for his kind gift of the S. tenebrarius strain, Kyowa Hakko Kogyo Co. Ltd., for their kind supply of sagamicin, and Miss N. SArto for technical assistance. We are indebted to Dr. H. NAGANAwA for determining the structure of phosphorylated dihydrostreptomycin. 


\section{References}

1) Vining, L. C.: Antibiotic tolerance in producing organisms. Adv. Appl. Microbiol. 25: 147 168, 1979

2) Yамамото, Н.; K. НоттA, Y. Oкамі \& H. Umezawa: Ribosomal resistance of an istamycin producer, Streptomyces tenjimariensis, to aminoglycoside antibiotics. Biochem. Biophys. Res. Comm. 100: 1396 1401, 1981

3) Нотта, К.; Н. Үамамото, Y. Окамі \& H. UmeZawa: Resistance mechanisms of kanamycin-, neomycinand streptomycin-producing streptomycetes to aminoglycoside antibiotics. J. Antibiotics 34: 1175 1182, 1981

4) Yамамото, H.; K. Нотta, Y. OKami \& H. UmeZawa: Self-resistance of a streptomycete which produces istamycins. J. Antibiotics 34: 824 829, 1981

5) Stark, W. M.; M. M. Hoehn \& N. G. Knox: Nebramycin, a new broad-spectrum antibiotic complex. I. Detection and biosynthesis. Antimicrob. Agents Chemother. -1967: 314 323, 1968

6) Higgens, C. E. \& R. E. Kastner: Nebramycin, a new broad-spectrum antibiotic complex. II. Description of Streptomyces tenebrarius. Antimicrob. Agents Chemother. -1967: 324 331, 1968

7) Ozanne, B.; R. Benveniste, D. Tipper \& J. Davies: Aminoglycoside antibiotics: Inactivation by phosphorylation in Escherichia coli carrying R factors. J. Bacteriol. 100: 1144 1146, 1969

8) Bock, K.; C. Pedersen \& H. Heding: A ${ }^{13}$ C NMR spectroscopic study of $\alpha$-and $\beta$-streptomycin. J. Antibiotics 27: 139 140, 1974

9) Yamaguchi, M.; S. Mitsuhashi, F. Kobayashi \& H. Zenda： 2'-N-Acetylating enzyme of aminoglycosides. J. Antibiotics 27: 507 515, 1974

10) Cheuereau, M.; P. J. L. Daniels, J. Davies \& F. Le Goffic: Aminoglycoside resistance in bacteria mediated by gentamicin acetyltransferase. II. An enzyme modifying the $2^{\prime}$-amino group of aminoglycoside antibiotics. Biochemistry 13: 598 603, 1974

11) Benveniste, R. \& J. Davies: Aminoglycoside antibiotic-inactivating enzymes in actinomycetes similar to those present in clinical isolates of antibiotic-resistant bacteria. Proc. Natl. Acad. Sci. USA 70: 2276 2280,1973

12) Demain, A. L.: How do antibiotic-producing microorganisms avoid suicide? Ann. New York Acad. Sci. 235: $601 \sim 612,1974$

13) Dowding, J. E.: A fifth class of aminoglycoside $3^{\prime}$-phosphotransferase from antibiotic-producing strains of streptomycetes. FEMS Microbiol. Lett. 6: 95 98, 1979 